\title{
Democratic values in Balinese traditional society: Analysis of the making and the content of Desa Pakraman's awig-awig
}

\author{
Unsur demokrasi pada masyarakat tradisional Bali: Tinjauan atas \\ pembuatan dan isi awig-awig Desa Pakraman
}

\author{
I Gst. Pt. Bagus Suka Arjawa \& I Gst. Agung Mas Rwa Jayantiari \\ Faculty of Social and Political Science, Universitas Udayana \\ Jalan PB. Sudirman, Denpasar, Bali. Telepon: 08124630641 \\ E-mail: suka_arjawa@yahoo.com
}

\begin{abstract}
This article describes the existence of democracy at a traditional level in Desa Pakraman in Bali. In Balinese society, Desa Pakraman is the root of social life, where people make interaction in culture and religion. Desa Pakraman is an organization underlies the life of Balinese society. Desa Pakraman has traditional instrument, called awig-awig. Awig-awig is an instrument of customary law in the society where the people have to obey the norms of the traditional law institution. Democratic practices and norms are apparent when people at Desa Pakraman build the awig-awig. Freedom of opinion can be found when people deliver their opinion we can find the equality of the human being. The research held in Desa Pakraman Penyalin, Tabanan, Bali, with qualitative method research. This research used democratic theory and participant theory. The research found that democracy has been practised at traditional society in Bali especially when people build the instrument of customary law. In Bali, this is called awig-awig. The awig-awig contains democratic instruments like equality before the law, human right and regular election to vote Desa Pakraman's officials.
\end{abstract}

Keywords: awig-awig, Desa Pakraman, democracy

\begin{abstract}
Abstrak
Tulisan ini memuat tentang keberadaan demokrasi pada lembaga tradisional, terutama di Desa Pakraman di Bali. Pada masyarakat Bali, Desa Pakraman merupakan akar dari kehidupan sosial, dimana masyarakat saling berinteraksi terutama pada bidang budaya dan keagamaan. Desa Pakraman merupakan organisasi dan lembaga yang hidup pada masyarakat Bali. Lembaga ini mempunyai alat kelengkapan tradisional yang disebut dengan awig-awig. Awig-awig merupakan instrumen hukum tradisional dimana masyarakat harus tunduk dari aturan-aturan yang telah ditetapkan pada awig-awig tersebut. Namun demikian, norma-norma dan praktik demokrasi, dapat dilihat ketika masyarakat di Desa Pakraman tersebut membuat awig-awig. Seperti demokrasi pada umumnya, disana dapat dilihat kebebasan masyarakat untuk mengutarakan pendapat dan persamaan derajat umat manusia. Penelitian ini dilakukan di Desa Pakraman Penyalin di Kabupaten Tabanan, Bali, dengan menggunakan metode kualitatif. Teori yang dipakai adalah teori tentang demokrasi serta teori partisipasi. Temuan penelitian adalah bahwa praktik demokrasi telah ditemukan pada masyarakat tradisional Bali, terutama pada saat masyarakat membuat instrumen lokal, yaitu awig-awig. Instrumen ini juga memuat berbagai norma tentang demokrasi seperti persamaan kedudukan di muka hukum, hak asasi manusia serta pemilihan pimpinan lembaga yang teratur.
\end{abstract}

Kata kunci: awig-awig, Desa Pakraman, demokrasi

\section{Introduction}

Democracy is understood as a governance system that provides an opportunity to the public audience to actively participate and develop the governance. The community involvement in the governance could be analyzed through how citizen articulates their opinion. This opinion provides a measurement standard about the quality and type of the development agenda. Antlov \& Wetterberg (2010:34) stated that democratic consolidation would be performed better with a higher level of sensitivity and 
interaction between citizen and states in the development plan. However, the traditional component of Indonesia society also delivers strong ideas to the democratic process reflected on local wisdom. In Bali, components of democracy are visible in the most basic institution of Hindu Society, known as Desa Pakraman (Suacana 2011). This institution unites Banjar-Banjar in Bali into a bond known as Khayangan Tiga, a place for Hindus to worship three God's mighty power; Brahma as the creator God, Wisnu as a protector God, and Shiva as the Destroyer of the universe.

Desa Pakraman has a diverse amount of population. To meet the requirement to be titled as a Desa Pakarman, a village should have a worship place called Khayangan Tiga. A big Desa Pakarman has 400 to 500 households. Several villages only have 55 people in the population, like in Desa Pakraman Penyalin, District of Tabanan (Wikertiditha 2016). Desa Pakraman has a rule called awigawig, a traditional rule that regulates the prevailing norms in the community related to worship place with the surrounding community. The creation of awig-awig should be derived from society aspiration expressed on the village gathering. The application of the voting system and discussion shows democratic aspect in the creation of awig-awig. The content of awig-awig that also hold the principles of democracy reflected on appreciation to the status of the community. Understanding awig-awig should be in accordance to customary law in order to create balance in the society (Artadi 2009: 82-84). In completing its activities, Desa Pakraman collected the villagers and asked for their opinion regarding religious ritual in the worship rites known as Khayangan Tiga. The Hindus in Bali are popular for their strict tradition in performing their religious ritual. To perform the ritual, Desa Pakraman behavior is based on the majority vote from the community deliberated in Awig-awig.

Wilujeng (2014:145-156) in his work titled "Meningkatkan Kualitas Hidup Berbangsa Melalui Budaya Demokrasi" (Improving Nation's Life Quality through Democratic Cultures), stated that democracy that has been formed since 2500 ago is still relevant for contemporary implementation. It was also argued that democracy created several issues in the nation-making process. Thus, in order to reduce the problems, there is a need to establish a civilized society based on the value of Pancasila.

Suacana (2011:88-136) in "Budaya Demokrasi dalam Kehidupan Masyarakat Desa di Bali" (Democratic culture in Balinese people" stated that many villages in Bali practice democracy in their daily life such as freedom of expression, regular election, and many more. Suacana frequently highlighted Bali Aga Village (Tenganan Pagringsingan, District of Karangasem) with Bali Majapahit (Desa Pakraman Mengwi, District of Badung).

Nugroho (2013: 247-262), in "Demokrasi dan Tata Pemerintahan dalam Konsep Desa dan Pemerintahan", argued that Indonesia had expressed its sovereignty on the hand of the citizen on its constitution, whether in the constitution preamble or the content. The villagers applied the value in Head of Village election always hold the principle of common interest instead of individual interest.

This article will contribute differently to Wilujeng's thinking that focuses on cultural-based democracy or Nugroho's writing that highlights the sovereignty of Head of Village election. The vocal point of this article is the democratic aspect in the voting process and community opinion absorption in the creation of awig-awig, consists of basic regulation of Desa Pakramana and the content of awig-awig. Therefore, the findings of their research also diverge from Suacana's research about democratic procedure in Desa Pakraman such as freedom of opinion and local head election.

Democracy is a ruling concept which expected to give a balance between right and responsibility of a citizen in the governance system. State, as an institution for citizen, applies the system in order to achieve justice in social life. The state is not only dominating the interest of the elites but also giving space to civilian to determine the governance system through a legal mechanism. The development of governance system influenced by a Western value which further developed by technology and communication lead to a substantial direct involvement by the citizen. A citizen could express their opinion through line call or send a letter to mass media or parliamentary institution. 
As a system that gives power to the citizen to be involved in the governance system, democracy could be traced back to the Greek Era. In the most ancient practice, about three up to six centuries $\mathrm{BC}$, democracy appeared in governance system in which citizen has the freedom to contribute to the political decision, with our majority procedure (Budiarjo 1985: 53-54). The understanding has been preserved until the recent time. Requirements of democracy have been developed, set human right and freedom of speech as the main concern.

In Bangkok Conference 1965, International Commission of Jurists had decided the requirement to establish a democratic governance under the rule of law; including constitutional protection. Constitutional protection should not only guarantee an individual right, but also decide procedural manner to gain protection of right, fair and neutral trial, fair and free election, freedom of speech, freedom to be in an organization or to be an opposition, and civic education (Budiarjo 1985:60).

Huntington, quoting Schumpeter, acknowledged individual participation in the making of the political decision. Schumpeter criticized several classic understanding which highlighted the importance of common interest and the will of the public. He argued that democracy is an institutional procedure to achieve a political decision in which individual has the power to influence and make a decision in a competitive manner in order to realize people voice. Furthermore, Huntington stated that democracy also implies the civil and political freedom such as freedom of speech, freedom to assemble and make the organization, which necessary in political debates and political campaign (Huntington 1997:5-6).

Mudjiani, Liddle and Ambardi (2012:76-77) expressed that the essence of democracy is participation. Quoting Verba, Schlozman and Brady, civil participation is the heart of democracy. According to Conway (2000), participation is trusted to determine the expected policy from the Government.

In the context of democracy that values equality, F.D. Hollemann stated that one characteristic of indigenous people is their commonality. Every individual and community member is an integral part of the whole society. Individual interest should be in accordance with communal interest since no individual could be disassociated from the community (Soemadiningrat 2011:31). This condition signifies there are equality and understanding of aspects of the community. Community participates in the national development process in order to implement democratic consolidation (Antlov \& Wettenberg 2010:34).

Therefore, civic involvement in the awig-awig making process is a demonstration of people participation in order to influence the decision-making process in Desa Pakraman, also an expression of freedom of speech and appreciation toward human rights. It was perceived that traditional institution in Indonesia, in this case, is Bali, had shown democratic behaviour as the democratic process expressed on the Western political system.

\section{Research Method}

This research applied qualitative research method. In this method, researchers conducted direct field observation in order to be able to closely captured the issue and digging the reality of social circumstances (Bryman 2004:267). Researchers had analyzed people custom, including their body gesture in delivering their opinion about awig-awig. The meeting was held in public hall of Desa Pakraman. Activities are being recorded and interpreted to reveal the value of speech during the meeting, to be reported in a writing. In hermeneutics theory, understanding should be based on interpretation (Gibbons, Noer Zaman, 2002: xiv). 


\section{Result and Discussion}

\section{Desa Pakraman}

Traditionally, the social structure in Bali is heavily influenced by Hinduism. The value of Hindu is reflected in the housing and social life. Desa Pakraman is the basic conception of Hindu-Balinese society which originated from Hindu prayer room, known as Khayangan Tiga. In the belief, God is manifested into three powers, as the creator, as the caretaker, and as the destructor. The God who has the power to create the universe and its content is Lord Brahma. God's power to take care of the earth and the content is Lord Wisnu, and Lord Shiva has the power to destruct the universe.

In the worship place, Lord of Brahma resides in a worship place called Pura Desa, Lord Wisnu resides in Pura Puseh and Lord Shiva resides in Pura Dalem. All of the three prayer rooms are used as the place to praise God or Hyang Widi. The Temple known as Khayangan Tiga, spread in the close distance but all located in one area. Three of them originated from the mighty God, therefore, Hindu people praise the three temples.

Khayangan Tiga temples are the origin of the existing Desa Pakraman. The village that protected the Khayangan Tiga Temple and the congregation is known as Desa Pakraman. Desa Pakraman is a community to praise God consists of many banjars from a different region. Banjar is a union of households located in one area.

In the past, the creation of the three temples required high cost and it was not possible to build Khayangan Tiga Temple in one Banjar. Thus, banjars were united and created one main Khayangan Tiga temple as the origin of Desa Pakraman. It is possible that one Desa Pakraman consists of one up to ten banjars, or more. In Tabanan Regency, Bali, Desa Pakraman Bede consists of 36 Pakraman banjars (Gunadnya 2016).

The most recent development of Desa Pakraman members shows the capability of Banjars to independently build their own Pura Khayangan Tiga. If a row is capable to build Khayangan Tiga Temple, the row could have the title as Desa Pakaraman, for example, is Desa Pakraman of Eka Cita in Banjar Penyalin, Tabanan. Another issue in the development of Desa Pakraman is no clear boundaries. The essence of the village is common prayer in one Pura Khayangan Tiga Temple. Thus, anyone who will to obey Pura Khayangan Tiga could be categorized as the member of Desa Pakraman.

\section{The function of Desa Pakraman}

Balinese local regulation number 06 the year 1986 article 1 stated that traditional village as a dresta village is a union of the society of custom law in the Bali province with one tradition and shared norms of Hindunese people under the bond of Kahyangan Tiga (Kahyangan Desa) with their own area and personal property. Article 5 of the regional rules stated that Desa Adat in is a union of society with the prevailing customary law with socio-religious and society centric aspect.

However, in Bali province, local regulation number 3 the year 2011 about Desa Pakraman (as it is changed into local regulation 3 the year 2003), the term of Desa Adat should not be used anymore. Article 1 of this regulation said that Desa Pakraman is a group of society of customary law in Bali with one tradition and shared norms of Hindunese people under the bond of Kahyangan Tiga (Kahyangan Desa). They have their own area and personal property and have the right to take care of their domestic household affairs. Given the change, the title of Desa Adat was changed into Desa Pakraman.

The duties of Desa Pakraman, as mentioned in article 5, local regulation of Bali Province Section 3, 2011, is making a wig-awig, managing the village, managing village's property, and together with the government is completing development in various sectors particularly in religion, culture, society, 
developing Balinese cultures in order to enrich, preserve, and develop national culture in general and local culture in particular based on discussion and consensus.

The right of Desa Pakraman as stated in article 6 in order to resolve custom and religion disputes within the area by preserving tolerance between the group. Village, according to awig-awig and the custom of the area should participate in decision making in development orientation in the area, according to Tri Hita Karana value.

The function of Desa Pakraman is indeed broad, related to various issues such as law, social, and the society. Given the board function, Desa Pakraman was once mentioned as a state within a state. According to Clifford Geertz (2000), Desa Pakraman could be identified as a mini republic with almost complete governing bodies. The identification of Desa Pakraman as a mini republic is due to the area, people, elites, and legal apparatus called awig-awig with the main function is to maintain order in the society.

\section{Explaining Awig-awig}

Section 1 article 3 of local regulation section 3 in 2001 stated that awig-awig is a regulation created by Desa Pakraman or Krama Banjar Pakraman which was used as guidelines in the implementation of Tri Hita Karana according to Desa Mawacara and religious value in Desa Pakraman/each Pakraman Banjar. Geertz (2000: 92) describes it as a written constitution in Banjar.

Given the definition of awig-awig, the function of Desa Pakraman is very board, even beyond what has performed by the village. Tri Hita Karana as a concept that should be taken into consideration in the social life as a base for the creation of awig-awig has a very comprehensive definition. Tri Hita Karana is a philosopical base of Hindunese people in Bali. The philosopy includes the relation between human and human, human and the surrounding environment, and the relation between human and God (Windia, Sudantra, 2016: 17-18). Given the context, the relation between human and social relations is a very complex behaviour, particularly human relation to God. Even though in the beginning, the definition of Desa Pakraman is only emphasizing the relation within Khayangan Tiga. However, the definition of awig-awig as expressed above

In awig-awig, customary law shows the magic and religious dimension (Pide 2015:11-12). In the context of Tri Hita Karana, a more complex social relations is apparent, involving people to people relations in daily life and its economic, culture, social, and political context. Even though in many cases Desa Pakraman engaged with the relation between human and God based on Khayangan Tiga, it involves social affairs in the discussion as well.

Local regulation Section 3 in 2001 about Desa Pakraman, which was transformed into Balinese local regulation Section 3 in 2003, is not clearly stating the equipment needed by Desa Pakraman. However, it can be said that there is an instrument in awig-awig which became the base of the activity. Awig-awig became the base of Desa Pakraman operation because awig-awig is the constitution of the institution. Awig-awig could expand and became a perarem, a normative rules according to the custom in the Desa Pakraman. Perarem could not be in opposition to the rules applied in awig-awig. It should be designed and applied to follow the local custom, which in the local language is known as dresta desa (Arnawa 2016). Perarem have the flexibility to change at different times, according to the social change in the moment. Several Desa Pakraman make a more specific regulation, known as Paswaran. Paswaran is a non-written arrangement with social norm function, as long as there is witness in the society.

Awig-awig is originated from the word "weg", interpreted as torn or broke in Balinese language. "Weg" having addition letter "a" in the beginning to negate the meaning of the word, in other word is interpreted as wholeness. The word was further developed into "awig", in which the repetition of the word is aimed to stress a subject as a united entity. Awig-awig, thus, means to preserve unity. The word is socially interpreted as a legal regulation to create a well-ordered society without the 
occurrence of conflict. Awig-awig contains prohibiton and obligation in the prayer room and talks about the village safety.

Another complementary tool of Desa Pakraman which preserves the social order is Pecalang. According to local regulation Section 3 in 2001, Pecalang has the function to maintain safety and order in Desa Pakraman in the relation to local task and religion. In the social practice, as long as the activity performed in the territory of Desa Pakraman, Pecalang can perform their duties such as to monitor vehicles in a parking space in ceremonial moments as activities related to safety and social order. Therefore, the job desk of Pecalang in the scope of safety is board. Moreover, there is no explanation about the word of "religion" in the local regulation, pecalang could also guard nonHindu ceremony.

To run the institution, Desa Pakraman also has Prajuru, consists of elites who run the village. The organizational structure with the right and obligation of the person was decided by awig-awig made by the people in Desa Pakraman. In Balinese society, from the historical point of view, there are two types of the inhabitant, Aga Balinese and Majapahit Balinese. Aga Balinese reside in the mountain area and regarded as the native which has been living in Bali for six centuries before the arrival of the Majapahit. The two groups stay in their own Desa Pakraman even in deciding the organizational structure of the Desa Pakraman, there are differences between the two of them.

As a group of people united with a common goal, Desa Pakraman occurred as a community who worship God through symbolization of Khayangan Tiga. Thus, Desa Pakraman also has limitation according to the number of community who obey the institution. The border of Desa Pakraman could not be decided through natural sign or human-made sign, but more to a union called Banjar Pakraman. Therefore, the border of Desa Pakraman could go beyond the institutional border or regency border.

\section{The element of democracy in the creation of awig-awig}

Desa Pakraman Penyalin is a village with 55 households, relatively small compared to other nearby villages. In 2002, this village decided to transform into a Desa Pakraman because it had established Pura Khayangan Tiga. According to the local regulation about Desa Pakraman, having the ability to build the worship space, Banjar Penyalin has the right to be titled as a Desa Pakraman. Aside from building Pura Khayangan Tiga, another requirement needed is to make awig-awig, a base to operate the institution. Desa Pakraman Penyalin started to develop awig-awig by stressing people sovereignty to create the rules. The practice of people sovereignty provide chances to the community to deliver their idea in the making of the basic regulation, thus, the value of democracy was shown from the activity.

The first aspect need to be taken into account is the presence of all members. In holding a meeting, all member of Desa Pakraman is present in the meeting hall, known as Bale Banjar. Members in this context are family members. The narrowest aspect of Desa Pakraman is family. For one people who represent family is adequate to deliver their idea and to give advice at the meeting. The representation should not always be men. Women are allowed to represent their family as well. In Desa Pakraman with one Banjar as the member, the meeting will be attended by all family members who met the age criteria. Husband, wife, and kids aged over than the minimum requirement are allowed to attend the meeting. The indicator of adulthood is determined by awig-awig of the Desa Pakraman.

Inviting people to attend the meeting in the meeting hall is the most basic practice of the implementation of democratic value. When Yunani first implemented democracy, all people were welcomed to give their opinion. For people of Desa Pakraman, the availability of meeting place makes the meeting possible. All Desa Pakraman is equipped with a meeting hall known as Balai Banjar. Furthermore, all worship prayer also has a meeting hall. In addition, the willingness to attend the meeting in the meeting hall indicates an effort to contribute in the discussion about religion and social affairs in the community. The conception of Tri Hita Karana enables Desa Pakraman to talk about social issues. 
The same thing applied to Desa Pakraman Penyalin. All adult family members were invited to attend the meeting regardless their sex. The meeting is not only conducted for once, but for multiple times until awig-awig had successfully created.

The next element of democracy is obedience to social norms. As a traditional institution, Desa Pakraman has a particular dress code. The rule is a social norm that has been implemented in Bali for centuries. The way someone dressed in Bali determines the first impression of the people. Traditionally, Balinese people wear destar and fabric as lower clothes. However, there is no obligation to wear a same-colored uniform.

In the meeting, the seat position also shows the democratic value for it represents squality and social position. The meeting attended by members of Desa Pakraman do not differentiate people with high or low social status. In Bali, the social status is divided into castes. Caste in Bali, in fact, refers colors that represent traditional ethic to describe a profession, but caste is socially interpreted as social vertical classification. Caste is apparent people manner when they sit, talk, or speak in daily life. In a meeting in Desa Pakraman, all members have the equal position. There is no differentiation between one party and another.

There are three castes in Desa Pakraman Penyalin, Ksatira, Wesya, and Sudra. However, in the seating position or in the manner of delivering their ideas, all people have an equal position without one party is socially higher than the other. The same situation applied to the practice of freedom of speech.

All members are allowed to propose opinion in Desa Pakraman regarding development and various social issues and how people performed their religion rites in the area. In Desa Pakraman, both of local languages or Bahasa Indonesia is allowed to use. Each opinion is further discussed to achieve consensus in the meeting. Such agreement is achieved through deliberation and consensus. However, deliberation and consensus could lead to suryak siu, an act of agreeing without considering the reason behind the opinion. Furthermore, the meeting also attended by elders and stakeholders of the Pura in order to avoid suryak siu.

All members are allowed to propose their opinion about awg-awig in the proper local language or in Indonesian. For them who cannot propose well in public, they are allowed to write down their opinion. This is to gather many opinions from the people so awig-awig could represent the people aspiration in a whole. The base of this advice is the conception of satya wacana (Purwita 1993:37). The concept stressed the importance of speaking the truth in line with the words that have been said. The members of Desa Pakraman Penyalin could propose their opinion in two ways, by speaking directly or by giving notes to be read by meeting secretary (penyarikan), to be discussed further.

The last step is making a decision. Balinese people have a basic conception in making a decision, known as paros-paros. In paros-paros, tolerance is regarded highly for a society to be able to live together orderly (Purwita 1993:37). The people of Desa Pakraman Penyalin expressed the phrase by listening, accepting, and organizing advice from the people. All opinion is recorded and discussed. The discussion was conducted by asking the opinion of the audience. In the end, agreement was taken by paros paros by deliberating to achieve consensus and providing a sense of communality towards opinions gathered.

\section{The element of democracy in awig-awig}

The creation of awig-awig shows high respect for democratic values such as appreciation to people. All people residing in Desa Pakraman Penyalin is regarded as a part of the community which deserves protection, whether they are native or migrant, even though particular rules are applied to non-native residents. Desa Pakraman also gives just obligation to their people. The native residents are obliged to do mutual cooperation (gotong royong) and the non-native like give a donation (section 4 and 5). 
In addition, people who are currently experiencing a bad situation or receiving governmental duties are allowed to receive less gotong royong tasks (section 7). Furthermore, Awig-awig also put a high respect on human rights. Appreciation on the human right has become a part of awig-awig in Desa Pakraman Penyalin, as stated in section 2. It is stated in the awig-awig that residents are the person who originally from the area, while migrant still deserves proper protection if they are exposed to any dangerous situation. Appreciation to the human right also received by orphans. They were nurtured by Desa Pakraman until they reach the age of 17. Orphans are free from any costs for living in Desa Pakraman Penyalin.

Desa Pakraman also conducts an election every five years to vote for village officials directly by the community. The presence of voters should be half plus one. The dismissal of officials or village elites requires citizen presence.

The third aspect is appreciation to the difference between citizens. Every decision making should be based on deliberation and consensus. If differences occurred, the discussion will be repeated for three times. If consensus still could not be achieved, the discussion will involve important figures in the village. Failure to do so will require discussion with the government.

\section{Conclusion}

Desa Pakraman in Bali, especially Desa Pakraman Penyalin, has implemented basic principles of democracy. The principle is to create stability and social order because Desa Pakraman is created to avoid inter-sect conflicts in Bali. Desa Pakraman also honors freedom of speech in a proper manner in delivering an opinion. The creation of Desa Pakraman is mostly initiated by its member. So does in rules making process which underlines the activity of the institution. The rules are known as awigawig and perarem. Democracy in Desa Pakraman could not be separated with the local wisdom in the area as they deliver the message that the local concepts are in accordance with the prevailing concepts applied in democracy. Awig-awig is the representation of how the institution absorbs aspiration of the society which eventually created rules with democratic values, such as appreciation for all elements in society before the law, appreciation towards people opinion and regular election to elect institution officials. Desa Pakraman does not differentiate women and men to be a leader or to have a position in the institution.

\section{References}

Antlov H \& Wetterberg A (2010) Masyarakat sipil, akuntabilitas publik, dan masa depan Pemerintah Daerah. Prisma, 29.

Arnawa IN (2016) [Personal communication] Mei.

Artadi I K ( 2009) Hukum Adat Bali dengan Aneka Masalahnya. Denpasar: Pustaka Balipost.

Bryman A (2004) Social Research Methods. Great Britain: Oxford University Press.

Budiardjo M (1985) Dasar-dasar Ilmu Politik. Jakarta: Gramedia.

Geertz C (2000) Negara Teater. Diterjemahkan: Hadikusumo \& Hartono. Yogyakarta: Bentang.

Gibbons MT (2002) Telaah Hermeneutis Wacana Sosial-Politik Kontemporer: Tafsir Politik. Translated by Noer Zaman A. Yogyakarta: Kalam.

Gunadnya IGPG (2016) [Personal communication] April.

Huntington SP (1997) Gelombang Demokrasi Ketiga. Translated by Marjohan A. Jakarta: Pustaka Utama Grafiti.

Mujani S (2012) Kuasa Rakyat: Analisis tentang Perilaku memilih dalam Pemilihan Legislatif dan Presiden Indonesia Pasca-Orde Baru. Bandung: Mizan.

Nugroho S (2013) Demokrasi dan tata pemerintahan dalam konsep desa dan pemerintahan. Jurnal Cita Hukum, 1 (2):247-262.

Peraturan Daerah Provinsi Bali No. 3 Tahun 2001 tentang Desa Pakraman.

Peraturan daerah Provinsi Bali No. 3 Tahun 2003, tentang Revisi atas Perda No. 3 Tahun 2001 tentang Desa Pakraman. 
Peraturan Daerah Provinsi Bali No. 6 Tahun 1986 tentang Kedudukan, Fungsi dan Peranan Desa Adat sebagai Kesatuan Masyarakat Hukum Adat dalam Propinsi Daerah Tingkat I Bali Awig-awig Desa Pakraman Eka Cita Desa Pakraman Penyalin.

Pide S \& Mustari (2015) Hukum Adat, Dahulu, Kini dan Akan Datang. Jakarta: PrenadaMedia. Purwita IBP (1993) Desa Adat Pusat Pembinaan Kebudayaan Bali. Denpasar: Upada Sastra.

Soemadiningrat \& Salman O (2011) Rekonseptualisasi Hukum Adat Kontemporer. Bandung: Alumni. Suacana IWG (2011) Budaya demokrasi dalam kehidupan masyarakat desa di Bali. Jurnal Kajian Bali, 1 (1).

Sudantra IK (2016) Pengakuan Peradilan Adat dalam Politik Hukum Kekuasaan Kehakiman. Denpasar: Bali Shanti.

Susila IGN (2016) [Personal communication] Juli.

Warren C (1993) Adat and Dinas, Balinese Communities in The Indonesia State. London: Oxford University Press.

Wikertiditha IGK (2016) [Personal communication] April.

Wilujeng \& Rahayu S (2014) Meningkatkan Kualitas Hidup Berbangsa Melalui Budaya Demokrasi. Humanika, 19 (1).

Windia WP \& Sudantra K (2016) Pengantar Hukum Adat Bali. Denpasar: Lembaga Dokumentasi dan Publikasi Fakultas Hukum Universitas Udayana. 